\title{
Familial Bone Marrow Monosomy 7 \\ Evidence That the Predisposing Locus Is Not on the Long Arm of Chromosome 7
}

\author{
Kevin M. Shannon, “ Ali G. Turhan, ${ }^{\ddagger 5}$ Sharon S. Y. Chang," Anne M. Bowcock," Paul C. J. Rogers,"* William L. Carroll,"¥

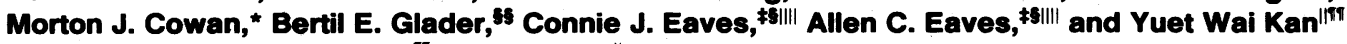 \\ Departments of *Pediatrics and "Medicine and "Howard Hughes Medical Institute, University of California, San Francisco, San \\ Francisco, California 94143; Departments of ${ }^{\ddagger}$ Pathology, ${ }^{* *}$ Pediatrics, and ${ }^{\prime \prime I}$ Medicine, University of British Columbia, and the ${ }^{\S}$ Terry \\ Fox Laboratory, British Columbia Cancer Centre, Vancouver, British Columbia, Canada; Departments of "Genetics and ${ }^{\$ \S}$ Pediatrics, \\ Stanford University Medical School, Stanford, California 94303; and ${ }^{\ddagger}$ Department of Pediatrics, Washington University School of \\ Medicine, St. Louis, Missouri 63110
}

\begin{abstract}
Loss of expression of a tumor-suppressing gene is an attractive model to explain the cytogenetic and epidemiologic features of cases of myelodysplasia and acute myelogenous leukemia (AML) associated with bone marrow monosomy 7 or partial deletion of the long arm (7q-). We used probes from within the breakpoint region on 7q- chromosomes (7q22-34) that detect restriction fragment length polymorphisms (RFLPs) to investigate three families in which two siblings developed myelodysplasia with monosomy 7 . In the first family, probes from the proximal part of this region identified DNA derived from the same maternal chromosome in both leukemias. The RFLPs in these siblings diverged at the more distal J3.11 marker due to a mitotic recombination in one patient, a result that suggested a critical region on 7q proximal to probe $\mathbf{J 3 . 1 1}$. Detailed RFLP mapping of the implicated region was then performed in two additional unrelated pairs of affected siblings. In these families, DNA derived from different parental chromosome $7 \mathrm{~s}$ was retained in the leukemic bone marrows of the siblings. We conclude that the familial predisposition to myelodysplasia is not located within a consistently deleted segment on the long arm of chromosome 7 . These data provide evidence implicating multiple genetic events in the pathogenesis of myelodysplasia seen in association with bone marrow monosomy 7 or $7 q$-.
\end{abstract}

\section{Introduction}

Complete monosomy 7 or partial deletion of the long arm (7q-) is a recurring cytogenetic abnormality in the bone marrows of patients with myelodysplasia and acute myelogenous leukemia $(\mathrm{AML})^{1}(1-4)$. The epidemiology of bone marrow monosomy 7 or $7 q$ - is striking. Monosomy 7 or $7 q$ - is the most common abnormal karyotype in cases of AML that occur after cytotoxic cancer therapy $(1,3)$ or occupational exposure to mutagens (5). Bone marrow monosomy 7 or $7 q-$ is also found in some patients with AML who have no prior history of car-

Address reprint requests to Dr. Yuet Wai Kan, Howard Hughes Medical Institute, University of California, San Francisco, CA 94143-0724. Received for publication 4 April 1989 and in revised form 15 May 1989.

1. Abbreviations used in this paper: AML, acute myeloblastic leukemia; RFLP, restriction fragment length polymorphism.

J. Clin. Invest.

(C) The American Society for Clinical Investigation, Inc.

0021-9738/89/09/0984/06 $\$ 2.00$

Volume 84, September 1989, 984-989 cinogen exposure $(3,6)$. The age distribution of these de novo cases shows peaks in the first and fifth decades (6). Overall, monosomy 7 or $7 q$ - is identified in $\sim 5 \%$ of de novo and in $40 \%$ of secondary cases of AML (1, 3-5). Although childhood bone marrow monosomy 7 is an uncommon disorder, it has been observed in two or more siblings at least seven times (7-10, Lange, B. J., personal communication, and our unpublished data).

The Knudson model of oncogenesis proposes that two mutational events (or "hits") which inactivate homologous alleles are required for a target cell to express a malignant phenotype $(11,12)$. Within the past two years, three groups have identified and cloned the first of this class of tumor suppressing genes-the retinoblastoma susceptibility gene (13-15). The cytogenetic and epidemiologic characteristics of bone marrow monosomy 7 suggest that loss of function at a locus on $7 q$ that normally limits myeloid proliferation is an important event in the development of myelodysplasia $(1,16)$. If the pathogenesis of this leukemia indeed follows the Knudson model, familial cases would arise when affected siblings inherit the same abnormal copy of this gene from one parent as the first mutation. In young children with the nonfamilial type of monosomy 7, the first "hit" would occur in a parental gamete or during early embryogenesis (similar to the mechanism in sporadic retinoblastoma). In patients who develop AML as a second malignancy, the initial mutation is presumably induced by exposure to the carcinogen. In all three instances, subsequent deletion of the homologous normal allele in a hematopoietic progenitor would lead to deregulation of growth and clonal expansion.

If loss of activity at a single locus on $7 q$ is sufficient to induce myelodysplasia, the putative gene should be located within the consistently deleted segment of the long arm (7q22-34) $(1-4,11,12)$. When applied to familial cases, this model predicts that the same parental chromosome (the one that carries the abnormal allele) will be retained in the leukemic bone marrows of siblings.

We used probes from the consistently deleted segment of chromosome 7 that identify restriction fragment length polymorphisms (RFLPs) to establish which parental chromosome was retained in the leukemic bone marrows of three unrelated pairs of siblings who developed AML with monosomy 7. The results of this analysis indicate that the familial predisposition to myelodysplasia is not located within this region on $7 q$.

\section{Methods}

Patients. Clinical features of family 1 have been the subject of a previous report (15). Briefly, cytogenetic analysis of the bone marrow of a 6-yr-old girl with AML showed monosomy 7. Her 5-yr-old brother shared HLA antigens and bone marrow transplantation was consid- 
ered. However, hematologic evaluation of the brother revealed mild thrombocytopenia, erythrocyte macrocytosis, and a minor subpopulation of bone marrow cells with the monosomy 7 abnormality. Over 3 yr of observation, he developed hepatosplenomegaly and circulating blasts associated with $100 \%$ monosomy 7 in unstimulated bone marrow cells. He died of infectious complications after receiving a haploidentical bone marrow transplant from his mother. Leukemic bone marrow from both siblings, uninvolved tissue from the son, and parental blood were available for analysis. Detailed clinical and cytogenetic information on the other two kindreds has been described elsewhere (16). In family 2, a diagnosis of myelodysplasia and monosomy 7 was made in female siblings at 16 and $17 \mathrm{yr}$. One then progressed rapidly to AML and died 19 mo later. The other had a longer myelodysplastic phase, but died 2 yr and 8 mo after diagnosis. The history in family 3 was remarkably similar to that in family 1 . A 4-yr-old boy presented with AML and monosomy 7 . When his $2 \frac{1}{2} 2$-yr-old brother was evaluated as a possible transplant donor, he was found to have peripheral pancytopenia and bone marrow monosomy 7 . The elder child has died, and the younger remains alive with myelodysplasia and pancytopenia. In families 2 and 3, DNA was extracted from the parents' leukocytes and from the patients' granulocytes or leukemic bone marrow. Granulocytes and monocytes in patients with monosomy 7 carry the chromosome 7 deletion (17). Informed consent was obtained for the laboratory studies.

DNA extraction and Southern blot procedure. High molecular weight DNA was prepared from tissue specimens by standard methods that included overnight digestion at $55^{\circ} \mathrm{C}$ in a solution consisting of $100 \mu \mathrm{g} / \mathrm{ml}$ of proteinase $\mathrm{K}$ (Beckman Instruments, Inc., Palo Alto, CA) and $0.5 \%$ SDS in Tris-Borate-EDTA buffer. This was followed by phenol/chloroform extraction, ethanol precipitation, treatment with RNase followed by SDS, additional phenol and chloroform extractions, and ethanol precipitation. The DNA was suspended in TE buffer consisting of $10 \mathrm{mM}$ Tris (pH 7.4) and 1 mM EDTA for digestion with restriction enzymes. A total of 5-10 $\mu \mathrm{g}$ of DNA was digested to completion with a variety of restriction endonucleases (New England Biolabs, Beverly, MA) according to manufacturer's instructions. After ethanol precipitation, the samples were resuspended in TE and separated by electrophoresis on $0.8 \%$ agarose gels. The gels were then stained with ethidium bromide, photographed, and transferred to nylon membranes (Hybond N; Amersham Corp., Arlington Heights, IL or Zetaprobe; Bio-Rad Laboratories, Richmond, CA).

Preparation of DNA probes. We obtained a series of single copy genomic DNA probes that detect RFLPs at loci on the long arm of chromosome 7. The specific probes and their locations on $7 q$ are shown on Fig. $1 a$. In the following list, the name of the probe used is given first and the locus or gene detected is indicated in parentheses. We are grateful to investigators who provided us with the following: Dr. Jeffery Browne (EPO (EPO) (18)), Dr. Peter Scambler and Dr. Robert Williamson (B79a (D7S13) (19), 7C22 (D7S18) (20), XV2c (D7S23) (21), J3.11 (D7S8) (22), and KM19 (D7S23)); Dr. Lap-Chee Tsui (A37 (D7S115) and C33 (D7S126) (23)); Dr. Fernando Ramirez and Dr. Petros Tsipouras (NJ3 (COL1A2) (24)); and Dr. Michael Dean and Dr. George Vande Woude (met 5 and 3H3 (MET) (25)), and Dr. David Ginsburg (PAI-1 (PLANH1) $(26,27)$ ). Probe KM19 detects a Pst I polymorphism with fragment sizes of 7.8 or $6.6 \mathrm{~kb}$ (Scambler, P. J., personal communication, 1988). We received probes met $\mathrm{H}$ and met $\mathrm{D}$ (MET) $(28,29)$ (originally isolated by Dr. Michael Dean and Dr. George Vande Woude) from Dr. Ray White and Dr. Peter O'Connell and probe TCRB (originally isolated by Dr. Tak Mak) from Dr. Art Weiss. DNA probes were labeled to high specific activity with ${ }^{32} \mathrm{P}-\mathrm{d}$ CTP using a commercial random priming kit (Multiprime DNA Labeling Kit; Amersham Corp.) and the filters were hybridized overnight. After washing, the filters were subjected to autoradiography.

\section{Results}

Family 1. Five of the probes tested were informative in this family. Autoradiographs of genomic Southern blots for these markers are shown in Fig. $1 \mathrm{~b}$. The type 1 plasminogen activator inhibitor gene (PAI-1) is located near the observed breakpoints in patients with myelodysplasia and partial deletion of the long arm (7q-) (30) and has been mapped to 7q 21.3-22 (27). Digestion of genomic DNA with Hind III generates alleles of either 22 or $18 \mathrm{~kb}$. As shown in Fig. $1 b$, the father is homozygous for the $18-\mathrm{kb}$ fragment, whereas the mother's digested DNA reveals both bands. Sibling 1 (the son) inherited a chromosome carrying the $22-\mathrm{kb}$ allele from his mother and an 18-kb allele from his father. Absence of the 18-kb band in his monosomy 7 bone marrow indicates that maternal DNA is retained in the leukemic clone. Similarly, his sister's bone marrow contains the $22-\mathrm{kb}$ allele, which must have originated on the same maternal chromosome. Probe $\mathrm{NJ} 3$ is derived from the alpha-2-collagen gene (Fig. $1 \mathrm{a}$ ) and detects alleles of 13.5 or $9.5 \mathrm{~kb}$ after digestion with Eco R1. Analysis with $\mathrm{NJ} 3$ reveals a unique $9.5 \mathrm{~kb}$ fragment inherited from the mother in the leukemic bone marrows of both children (Fig. $1 \mathrm{~b}$ ). Probe B79a (Fig. $1 a$ ) detects alleles of either 10.6 or $8.4 \mathrm{~kb}$ after digestion with Msp I. The parents are homozygous for different alleles (Fig. $1 b$ ). As expected, analysis of the normal tissues of sibling 1 reveals both bands. The monosomy 7 bone marrows of both siblings shows a single band at $8.4 \mathrm{~kb}$, confirming that the DNA in both leukemias originated on a maternal chromosome. After digestion with Msp I, probe J3.11 identifies an RFLP with alleles of 4.1 or $1.7 \mathrm{~kb}$. Sibling 1 inherited a chromosome containing the 1.7-kb allele from his mother (who is heterozygous at this locus), and a 4.1-kb fragment from his father (who is homozygous for the 4.1-kb allele). The maternal 1.7-kb allele is present in his leukemic bone marrow, a result consistent with those obtained with more proximal markers. However, the leukemic bone marrow of sibling 2 shows a 4.1-kb fragment, indicating that the DNA originated on a different chromosome that she could have inherited from either parent. As shown in Fig. $1 b$, analysis with the more distal C33 marker demonstrates a mitotic recombination in the leukemic bone marrow of sibling 2. Probe C33 detects alleles of $4.0,3.5$, or $3.0 \mathrm{~kb}$ in DNA digested with Eco R1. The mother is homozygous for the $3.0-\mathrm{kb}$ allele; the father is heterozygous for the 3.5 - and $3.0-\mathrm{kb}$ alleles. The paternal chromosome bearing the $3.5-\mathrm{kb}$ allele is seen in the normal tissue of sibling 1 and is lost from his bone marrow, indicating that maternal DNA is retained in the leukemic clone. In contrast, bone marrow from sibling 2 shows a $3.5-\mathrm{kb}$ restriction fragment that she inherited from her father. A mitotic recombination must have occurred between the loci detected by probes B79a (D7S13) and C33 (D7S126) in the single chromosome 7 retained in the leukemic clone of sibling 2, because DNA from the mother is present proximally, while paternal DNA is observed after analysis with C33. Because RFLPs in the leukemic bone marrows already diverge at the locus detected by probe J3.11 (D7S8), it seems likely that the recombination occurred proximal to this site.

Families 2 and 3. The results in family 1 suggested that a putative leukemia-suppressing locus might exist within the consistently deleted segment of chromosome 7 proximal to the DNA sequence detected by probe J3.11 (7q21-31.1). To further test the underlying model, we examined this region in families 2 and 3. Data from the informative markers are presented in Table I. In Family 2, probes EPO, PAI-1, XV2c, $\mathrm{J} 3.11$, and $\mathrm{C} 33$ detected different alleles in the leukemic bone marrows of the siblings. The interpretation of these data is that 


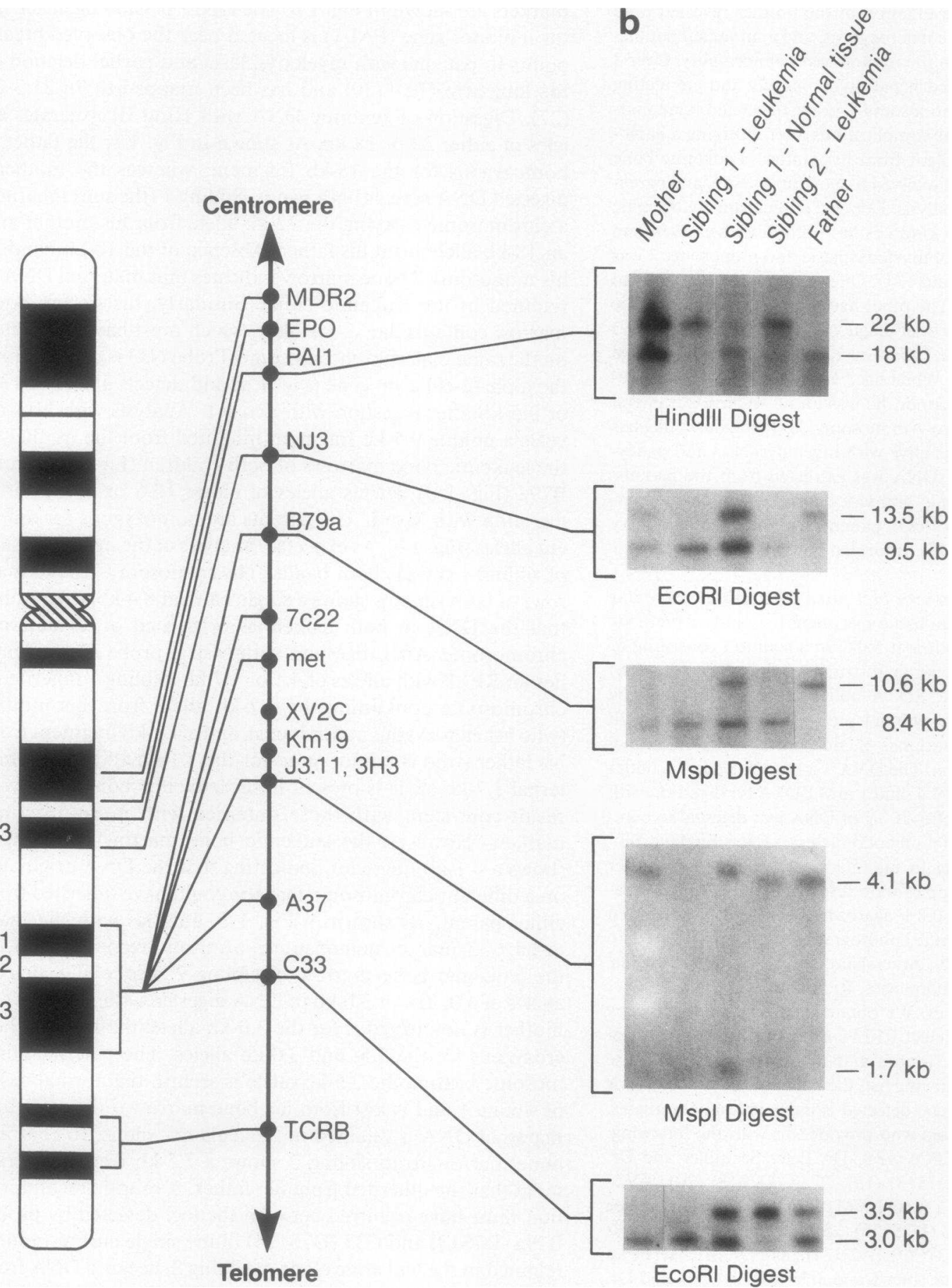

Figure 1. (a) Locations of the probes on the long arm of chromosome 7 used for analysis of familial bone marrow monosomy 7 derived from published linkage maps $(23,32,43)$ and unpublished information (Scambler, P. J., personal communication). (b) Genomic Southern blots from family 1 .

the DNA in the leukemic bone marrow of sibling 1 was inherited from her father, while that in the bone marrow of sibling 2 originated on one of the mother's chromosomes. Probes MDR-2, PAI-1, NJ3, B79a, met D, and J3.11 were informative in family 3 (Table I). A unique maternal allele is identified in the leukemic bone marrow of sibling 1 with probes J3.11 and NJ3. Results of analysis with B79a and PAI-1 reveal DNA derived from the mother's other chromosome 7 in the bone marrow of sibling 2. Most importantly, the alleles detected in the leukemic bone marrows of these brothers differ at all six informative loci within the $25-40 \mathrm{cM}$ region of interest. The D7S13 locus detected by probe B79a is situated near the middle of this region with the loci identified by probes $\mathrm{J} 3.11$ and met D 5-15 cM away and toward the telomere and markers NJ3, PAI-1 and MDR-2 15-25 cM nearer to the centromere (Fig. 1 a). A double mieotic recombination between any two of 
Table I. RFLP Analysis of DNA Extracted from Parental Leukocytes and Patient Monosomy 7 Cells in Families 2 and 3

\begin{tabular}{llcccc}
\hline Probe & Enzyme & Mother & Sibling 1 & Sibling 2 & Father \\
\hline Family 2 & & & & & \\
EPO & Hind III & $26 / 14$ & $26 /-$ & $14 /-$ & $26 / 26$ \\
PAI-1 & Hind III & $22 / 22$ & $18 /-$ & $22 /-$ & $22 / 18$ \\
XV2c & Taq I & $2.1 / 2.1$ & $1.6 /-$ & $2.1 /-$ & $2.1 / 1.6$ \\
J3.11 & Msp I & $4.1 / 4.1$ & $1.7 /-$ & $4.1 /-$ & $1.7 / 1.7$ \\
C33 & Eco RI & $3.0 / 3.0$ & $3.5 /-$ & $3.0 /-$ & $3.5 / 3.0$ \\
Family 3 & & & & & \\
MDR-2 & Eco RI & $4.5 / 3.1$ & $3.1 /-$ & $4.5 /-$ & $4.5 / 3.1$ \\
PAI-1 & Hind III & $22 / 18$ & $22 /-$ & $18 /-$ & $22 / 22$ \\
NJ3 & Eco RI & $13.5 / 9.5$ & $13.5 /-$ & $9.5 /-$ & $9.5 / 9.5$ \\
B79a & Msp I & $11.6 / 8.4$ & $8.4 /-$ & $11.6 /-$ & $8.4 / 8.4$ \\
Met D & Taq I & $5.5 / 4.3$ & $5.5 /-$ & $4.3 /-$ & $5.5 / 4.3$ \\
J3.11 & Msp I & $4.1 / 1.7$ & $1.7 /-$ & $4.1 /-$ & $4.1 / 4.1$ \\
& & & & & \\
\hline
\end{tabular}

these loci would be necessary to produce a region in which DNA from the same maternal chromosome 7 was retained in both leukemic clones. Because of the small genetic distances involved, this is highly unlikely.

\section{Discussion}

These three families in whom two siblings developed myelodysplasia or AML with bone marrow monosomy 7 allowed us to directly test the hypothesis that inactivation of both alleles of a putative tumor-suppressing locus on the long arm of chromosome 7 is sufficient to cause myelodysplasia. The finding that the leukemic bone marrows of two of three pairs of siblings retained DNA inherited from different parental chromosomes argues against this proposed model.

Molecular and cytogenetic investigation of patients with myelodysplasia and 7q- implicates 7q21-34 as the critical region of interest. Kere and associates $(17,30,31)$ used probes which detect RFLPs to analyze loss of heterozygosity in the 7qbone marrows of four unrelated patients with myelodysplasia and concluded that the region distal to EPO and proximal to TCRB (Fig. $1 a$ ) was consistently deleted. Cytogenetic analysis of patients with myelodysplasia and AML reveals many with partial deletions of the long arm of chromosome 7 (1-4). At least 20 such patients have much of the long arm deleted (q22-qter) (1-4). In addition, a few cases have been observed with more limited interstitial (q22-q34) $(3,17,31)$ or distal (q34-qter) $(2,3)$ deletions. Our results indicating that the genetic lesion responsible for the familial predisposition to myelodysplasia is not located within this commonly deleted segment might be interpreted in two ways. It is formally possible that loss of the long arm of chromosome 7 is an incidental finding in myelodysplasia and AML and that this loss is unrelated to the development and progression of the disease. A more likely hypothesis is that chromosome 7 deletions are "necessary but not sufficient" to cause myelodysplasia. According to this second model, at least one additional genetic lesion located outside of the deleted segment on chromosome 7 is required for the clinical disease. Although there is insufficient information to distinguish between these possibilities, the strong epidemiologic association of monosomy 7 with myelo- dysplasia and AML suggests that these chromosomal deletions are of pathogenic importance. An interesting question is whether these characteristic chromosome 7 deletions are accompanied by loss of function of both alleles (as appears to be the case in retinoblastoma), or leads to hemizygosity. Isolation of the putative gene from the long arm of chromosome 7 will be required to distinguish between these possibilities.

Recent studies in two familial cancers show that the inherited predisposition may not map within commonly deleted DNA segments. Multiple endocrine neoplasia type 2 (MEN2) is a dominant familial syndrome characterized by neoplasias of the thyroid, adrenal, and parathyroid. The familial predisposition to MEN2 maps to chromosome 10; however, nonrandom reduction to homozygosity has been demonstrated for alleles on chromosome 1 (32-34). In addition, familial Wilms' tumor is not linked to the commonly deleted segment of chromosome $11 \mathrm{p}(35,36)$. In contrast to Wilms' tumor and MEN2, multigenerational families in whom bone marrow monosomy 7 is apparently transmitted as a single gene defect have not been described. However, ascertaining inheritance is difficult because children who develop the familial type of monosomy 7 rarely survive to reproductive age. Five of our six patients are dead and the sixth is alive with myelodysplasia and pancytopenia. The early age of onset in familial bone marrow monosomy 7 and the remarkable finding of at least seven unrelated pairs of siblings with this rare disorder (7-10) are consistent with an inherited predisposition to cancer.

Results in monosomy 7, Wilms' tumor and MEN2 suggest the existence of two broad categories of familial cancer genes. In the first type, the familial tendency to develop cancer maps within the deleted segment of DNA. It is likely that homozygous loss of function at a single allele is sufficient to produce the malignant phenotype. Retinoblastoma is the prototype for this type of disorder. Cytogenetic and linkage data in multiple endocrine neoplasia type 1 (37), familial adenomatous polyposis $(38,39)$, and bilateral acoustic neuroma (neurofibromatosis 2$)(40,41)$ suggest that these neoplasms might follow this single locus model. A second group would include those cancers in which the inherited predisposition is not physically linked to commonly deleted segments of DNA. In these disorders, it seems likely that mutations of least two genes are required for the development of cancer. Wilms' tumor, MEN2, and familial bone marrow monosomy 7 apparently follow this second pattern. The recent demonstration of multiple accumulated genetic lesions in advanced stage glioma provides evidence supporting a multistep model of oncogenesis in some human cancers (42).

In practical terms, the observation that familial bone marrow monosomy 7 does not map within the commonly deleted area will impede efforts to precisely identify a critical region on 7q. Future studies should focus on localizing the familial predisposition to facilitate counseling of affected families, and on defining where the putative myelodysplasia locus lies on 7q. Ultimately, molecular cloning of these myelodysplasia susceptibility genes and functional characterization of their protein products will afford insights into the control of hematopoietic differentiation and mechanisms of leukemogenesis.

\section{Acknowledgments}

The authors wish to acknowledge Dr. Peter Scambler (St. Mary's Hospital, London) and Dr. L.-C. Tsui (Hospital for Sick Children, To- 
ronto) for their constant encouragement, advice, and for their willingness to share unpublished data and to hybridize filters with recently isolated probes. We obtained some patients samples through collaboration with the Childrens Cancer Study Group (CCSG Study B024). We are also indebted to Drs. Jane Gitschier, Michelle LeBeau, Peter O'Connell, Charles Epstein, Steve Schoenberg, Steve Smith, and Bernie Morley and to Barbara Levinson for critical comments and advice and to Jennifer Gampbell for editorial suggestions.

Y. W. Kan is an Investigator of the Howard Hughes Medical Institute. K. M. Shannon is an out-service fellow of the Naval Health Sciences Education and Training Command, Bethesda, MD. A. G. Turhan is a Fellow of the Medical Research Council of Canada. C. J. Eaves is a Terry Fox Research Scientist of the National Cancer Institute of Canada. This work was supported, in part, by a grant from the National Cancer Research Institute of Canada. The opinions and assertions expressed in this paper are those of the authors and do not necessarily reflect the views of the Navy Department or of the Naval Service at large.

\section{References}

1. LeBeau, M. M., K. S. Albain, R. A. Larson, J. W. Vardiman, E. M. Davis, R. R. Blough, H. M. Golomb, and J. D. Rowley. 1986. Clinical and cytogenetic correlations in 63 patients with therapy-related myelodysplastic syndromes and acute nonlymphocytic leukemia: further evidence for characteristic abnormalities of chromosomes no. 5 and 7. J. Clin. Oncol. 3:325-345.

2. Yunis, J. J., R. E. Rydell, M. M. Oken, M. A. Arnesen, M. G. Mayer, and M. Lobell. 1986. Refined chromosome analysis as an independent prognostic indicator in de novo myelodysplastic syndrome. Blood. 67:1721-1730.

3. The Fourth International Workshop on Chromosomes in Leukemia: a prospective study of acute nonlymphoblastic leukemia. 1984. Cancer Genet. Cytogenet. 11:249-360.

4. Bloomfield, C. D., and A. de la Chapelle. 1987. Chromosome abnormalities in acute nonlymphocytic leukemia: clinical and biologic significance. Semin. Oncol. 14:372-382.

5. Golomb, H. M., G. Alimena, J. D. Rowley, J. W. Vardiman, J. R. Testa, and C. Sovik. 1982. Correlation of occupation and karyotype in adults with acute nonlymphocytic leukemia. Blood. 60:404411.

6. Michiels, J. J., H. Mallios-Zorbala, M. E. F. Prins, K. Hahlen, and A. Hagmeijer. 1986. Simple monosomy 7 and myelodysplastic syndrome in 13 patients without previous cytostatic treatment. Br. $J$. Hematol. 64:425-434.

7. Carroll, W. L., R. Morgan, and B. E. Glader. 1985. Childhood bone marrow monosomy 7 syndrome: a familial disorder? J. Pediatr. 107:578-580.

8. Larsen, W. E., and R. N. Schimke. 1976. Familial acute myelogenous leukemia with associated C-monosomy in two affected members. Cancer (Phila.). 38:841-845.

9. Kamiyama, R., T. Shibata, and W. Mori. 1973. Two autopsy cases of atypical myeloproliferative disorder with group $\mathrm{C}$ monosomy occurring in siblings. Acta Pathol. Jpn. 23:815-821.

10. Li, F., F. Hecht, B. Kaiser-McCaw, P. V. Baranko, and N. U. Potter. 1981. Ataxia-pancytopenia syndrome of cerebellar ataxia, hypoplastic anemia, monosomy 7 , and acute myelogenous leukemia. Cancer Genet. Cytogenet. 4:189-195.

11. Knudson, A. G. 1985. Hereditary cancer, oncogenes and antioncogenes. Cancer Res. 45:1437-1443.

12. Cavenee, W. K., T. P. Dryja, R. A. Phillips, W. F. Benedict, R. Godbout, B. L. Gallie, A. L. Mumphree, L. C. Strong, and R. L. White. 1983. Expression of recessive alleles by chromosomal mechanisms in retinoblastoma. Nature (Lond.). 305:779-784.

13. Friend, S. H., R. Bernards, S. Rogel, R. A. Weinberg, J. M. Rapaport, D. M. Albert, and T. P. Dryja. 1986. A human DNA segment with properties of the gene that predisposes to retinoblastoma and osteosarcoma. Nature (Lond.). 323:643-646.
14. Lee, W-H, R. Bookstein, F. Hong, L.-H. Young, J.-H. Shew, and E. Y.-H.P. Lee. 1987. Human retinoblastoma susceptibility gene: cloning identification and sequence. Science (Wash. DC). 235:13941399.

15. Fung, Y.-K. T., A. L. Mumphree, A. T'Ang, J. Qian, S. H. Hinrichs, and W. F. Benedict. 1987. Structural evidence for the authenticity of the human retinoblastoma gene. Science (Wash. DC). 236:1657-1661.

16. Brandwein, J. M., D. E. Horsman, A. C. Eaves, C. J. Eaves, B. G. Massing, L. D. Wadsworth, P. C. J. Rogers, and D. K. Kalousek. 1989. Childhood myelodysplasia: suggested classification as myelodysplastic syndromes. Am. J. Pediatr. Hematol. Oncol. In press.

17. Kere, J., T. Ruutu, and A. de la Chapelle. 1987. Monosomy 7 in granulocytes and monocytes in myelodysplastic syndrome. N. Engl. J. Med. 316:499-503.

18. Law, M. L., G.-Y. Cai, F.-K. Lin, Q. Wei, S.-Z. Huang, J. H. Hartz, H. Morse, C.-H. Lin, C. Jones, and F.-T. Kao. 1986. Chromosomal assignment of the human erythropoietin gene and its DNA polymorphism. Proc. Natl. Acad. Sci. USA. 83:6920-6924.

19. Estivill, X., J. Schmidke, R. Williamson, and B. Wainwright. 1986. Chromosome assignment and restriction fragment polymorphism analysis of the anonymous DNA probe B79a at 7q22. Hum. Genet. 74:320-322.

20. Scambler, P. J., B. J. Wainwright, E. Watson, G. Bates, G. Bell, R. Williamson, and M. Farrall. 1986. Isolation of a further anonymous informative DNA sequence from chromosome seven closely linked to cystic fibrosis. Nucleic Acids Res. 14:1951-1956.

21. Estivill, X., M. Farrall, P. J. Scambler, G. M. Bell, K. M. F. Hawley, N. J. Lench, G. P. Bates, H. C. Kruyer, P. A. Frederick, P. Stanier, E. K. Watson, R. Williamson, and B. J. Wainwright. 1987. A candidate for the cystic fibrosis locus isolated by selection for methylation-free islands. Nature (Lond.). 326:840-845.

22. Wainwright, B. J., P. J. Scambler, E. Watson, G. Bates, G. Bell, R. Williamson, and M. Farrall. 1985. Localization of cystic fibrosis to human chromosome 7cen-q22. Nature (Lond.). 318:384-385.

23. Rommens, J., S. Zengerling, J. Burns, G. Melmer, B. Kerem, N. Plavsic, M. Zsiga, D. Kennedy, D. Markiewicz, R. Rozmahel, J. R. Riordan, M. Buchwald, and L.-C. Tsui. 1988. Identification and regional localization of DNA markers on chromosome 7 for the cloning of the cystic fibrosis gene. Am. J. Hum. Genet. 43:645-663.

24. Tsipouras, P., J. C. Myers, F. Ramirez, and D. J. Prokop. 1983. Restriction fragment length polymorphism associated with the proalpha(2) gene of human type I procollagen. J. Clin. Invest. 72:12621267.

25. Dean, M., P. O’Connell, M. Leppert, M. Park, J. A. Amos, D. G. Phillips, R. White, and G. F. Vande Woude. 1987. Three additional DNA polymorphisms in the met gene and D7S8 locus: use in prenatal diagnosis of cystic fibrosis. J. Pediatr. 111:490-495.

26. Ginsburg, D., R. Zeheb, A. Y. Yang, U. M. Rafferty, P. A. Andreasen, L. Nielsen, K. Dano, R. V. Lebo, and T. D. Gelehrter. 1986. cDNA cloning of human plasminogen activator-inhibitor from endothelial cells. J. Clin. Invest. 78:1673-1680.

27. Klinger, K. W., R. Winqvist, A. Riccio, P. A. Andreasen, R. Sartorio, L. S. Nielsen, N. Stuart, P. Stanislovitis, P. Watkins, R. Douglas, K. H. Grzeschik, K. Alitalo, F. Blasi, and K. Dano. 1987. Plasminogen activator inhibitor type 1 gene is located at region q21.3q22 of chromosome 7 and is genetically linked with cystic fibrosis. Proc. Natl. Acad. Sci. USA. 84:8548-8552.

28. White, R., S. Woodward, M. Leppert, P. O'Connell, M. Hoff, J. Herbst, J.-M. Lalouel, M. Dean, and G. Vande Woude. 1985. A closely linked genetic marker for cystic fibrosis. Nature (Lond.). 318:382-384.

29. Dean, M., M. Park, M. M. LeBeau, T. S. Robins, M. O. Diaz, J. D. Rowley, D. G. Blair, and G. F. Vande Woude. 1985. The human met oncogene is related to the tyrosine kinase oncogenes. Nature (Lond.). 318:385-388.

30. Kere, J., T. Ruutu, K. A. Davies, I. B. Roninson, P. C. Watkins, R. Winqvist, and A. de la Chapelle. 1989. Chromosome 7 long arm 
deletions in myeloid disorders: a narrow breakpoint region in $7 \mathbf{q} 22$ defined by molecular mapping. Blood. 73:230-234.

31. Kere, J., T. Ruutu, R. Lahtinen, and A. de la Chapelle. 1987. Molecular characterization of chromosome 7 long arm deletions in myeloid disorders. Blood. 70:1349-1353.

32. Mathew, C. G. P., B. A. Smith, K. Thorpe, Z. Wong, N. J. Royle, A. J. Jeffreys, and B. A. J. Ponder. 1987. Deletion of genes on chromosome 1 in endocrine neoplasia. Nature (Lond.). 328:524-526.

33. Mathew, C. G. P., K. S. Chin, D. F. Easton, K. Thorpe, C. Carter, G. I. Liou, S.-L. Fong, C. D. B. Bridges, H. Haak, A. C. Nieuwenhuijzen Kruseman, S. Schifters, H. H. Hansen, H. Telenius, M. Telenius-Berg, and B. A. J. Ponder. 1987. A linked genetic marker for multiple endocrine neoplasia type $2 \mathrm{~A}$ on chromosome 10. Nature (Lond.). 328:527-528.

34. Simpson, N. E., K. K. Kidd, P. J. Goodfellow, H. McDermid, S. Myers, J. R. Kidd, C. E. Jackson, A. M. V. Duncan, L. A. Farrer, K. Brasch, C. Castiglione, M. Genel, J. Gertner, C. R. Greenberg, J. F. Gusella, J. J. A. Hodlen, and B. N. White. 1987. Assignment of multiple endocrine neoplasia type $2 \mathrm{~A}$ to chromosome 10 by linkage. Nature (Lond.). 328:528-530.

35. Grundy, P., A. Koufos, K. Morgan, F. P. Li, A. T. Meadows, and W. K. Cavanee. 1988. Familial predisposition to Wilms' tumor does not map to the short arm of chromosome 11. Nature (Lond.). 336:374-376.

36. Huff, V., D. A. Compton, L.-Y. Chao, L. C. Strong, C. F. Geiser, and G. F. Saunders. Lack of linkage of familial Wilm's tumor to chromosomal band 11p13. Nature (Lond.). 336:377-378.

37. Larsson, C., B. Skogseid, K. Oberg, Y. Nakamura, and M.
Nordenskjold. 1988. Multiple endocrine neoplasia type 1 gene maps to chromosome 11 and is lost in insulinoma. Nature (Lond.). 332:85-87.

38. Bodmer, W. F., C. J. Bailery, J. Bodmer, H. J. R. Bussey, A. Ellis, P. Gorman, F. C. Lucibello, V. A. Murday, S. H. Rider, P. Scambler, D. Scheer, E. Solomon, and N. K. Spurr. 1987. Localization of the gene for familial adenomatous polyposis on chromosome 5 . Nature (Lond.). 328:614-616.

39. Solomon, E., R. Voss, V. Hall, W. F. Bodmer, J. R. Jass, A. J. Jeffreys, F. C. Lucibello, I. Patel, and S. H. Rider. 1987. Chromosome 5 allele loss in human colorectal carcinomas. Nature (Lond.). 328:616-619.

40. Seizinger, B. R., R. L. Martuza, and J. Gusella. 1986. Loss of genes on chromosome 22 in tumorigenesis of human acoustic neuroma. Nature (Lond.). 332:644-647.

41. Rouleau, G. A., W. Wertelecki, J. L. Haines, W. J. Hobbs, J. A. Trofatter, B. R. Seizinger, R. L. Martuza, D. W. Superneau, P. N. Conneally, and J. Gusella. 1987. Genetic linkage of bilateral acoustic neuroma to a DNA marker on chromosome 22. Nature (Lond.). 329:5419-5423.

42. James, C. D., E. Carlbom, J. P. Dumanski, M. Hansen, M. Nordenskjold, V. P. Collins, and W. K. Cavenee. 1988. Clonal genomic alterations in glioma malignancy stages. Cancer Res. 48:55465551.

43. Lathrop, G. M., M. Farrall, P. O'Connell, B. Wainwright, M. Leppert, Y. Nakamura, N. Lench, H. Kruyer, M. Dean, M. Park, G. Vande Woude, J.-M. Lalouel, R. Williamson, and R. White. 1988. Refined linkage map of chromosome 7 in the region of the cystic fibrosis gene. Am. J. Hum. Genet. 42:38-44. 